\title{
A comparison of bacteremic pneumococcal pneumonia with nonbacteremic community-acquired pneumonia of any etiology - Results from a Canadian multicentre study
}

\author{
Thomas J Marrie MD ${ }^{1}$, Donald E Low MD², Emidio de Carolis $\mathrm{PhD}^{3}$ \\ and the Canadian Community-Acquired Pneumonia Investigators
}

\begin{abstract}
TJ Marrie, DE Low, E de Carolis and the Canadian CommunityAcquired Pneumonia Investigators. A comparison of bacteremic pneumococcal pneumonia with nonbacteremic communityacquired pneumonia of any etiology - Results from a Canadian multicentre study. Can Respir J 2003;10(7):368-374.
\end{abstract}

BACKGROUND: Bacteremic pneumococcal pneumonia has not been the subject of a multicentre Canadian Study.

OBJECTIVES: To compare bacteremic community-acquired Streptococcus pneumoniae pneumonia with nonbacteremic communityacquired pneumonia of any etiology.

METHODS: A prospective cohort study was conducted at 15 centres in eight Canadian provinces from January 1996 to January 1998. RESULTS: Fifty-six of the 450 patients (12.4\%) had one or more blood cultures positive for $S$ pneumoniae. Compared with the 394 blood culture-negative patients, the bacteremic patients were younger (55.6 years versus 63.4 years; $\mathrm{P}=0.002$ ). At presentation, bacteremic patients had a higher mean oral temperature $\left(38.1 \pm 1.2^{\circ} \mathrm{C}\right.$ versus $\left.37.7 \pm 1.2^{\circ} \mathrm{C} ; \mathrm{P}=0.026\right)$, a higher pulse rate $(108.4 \pm 22.1$ beats $/ \mathrm{min}$ versus $102.1 \pm 20.6$ beats $/ \mathrm{min} ; \mathrm{P}=0.033)$, a lower diastolic blood pressure reading $(66.8 \pm 12.7 \mathrm{mmHg}$ versus $73.8 \pm 15.8 \mathrm{mmHg} ; \mathrm{P}=0.001)$ and a higher percentage of white blood cells that were band forms ( $22.1 \%$ versus $14.2 \% ; \mathrm{P}=0.0007)$. The time from onset of symptoms until admission to hospital was shorter among the bacteremic patients $(4.6 \pm 3.7$ days versus $7.0 \pm 13.9$ days; $\mathrm{P}=0.005)$. Three capsular polysaccharide types accounted for $53.4 \%$ of the isolates: type 14 , $29.2 \%$; type $4,12.1 \%$; and type $22 \mathrm{~F}, 12.1 \%$. Two of 44 isolates were resistant to penicillin.

CONCLUSIONS: While some differences in patient characteristics and presentation occur when patients with bacteremic pneumococcal pneumonia are compared with nonbacteremic patients with community-acquired pneumonia, there is considerable overlap, and clinical presentation does not allow one to distinguish the bacteremic patients from the nonbacteremic patients.

Key Words: Bacteremia; Epidemiology; Pneumonia; Resistance; Streptococcus pneumoniae
Une comparaison entre la pneumonie bactériémique à pneumocoques et la pneumonie non bactériémique de toute étiologie acquise dans la collectivité : Les résultats d'une étude multicentre canadienne

HISTORIQUE : La pneumonie bactériémique à pneumocoques n'a fait l'objet d'aucune étude multicentre canadienne.

OBJECTIFS : Comparer la pneumonie bactériémique à Streptococcus pneumoniae acquise dans la collectivité à la pneumonie non bactériémique de toute étiologie acquise dans la collectivité.

MÉTHODOLOGIE : Une étude prospective de cohorte a été menée dans 15 centres de huit provinces canadiennes entre janvier 1996 et janvier 1998.

RÉSULTATS : Cinquante-six des 450 patients $(12,4 \%)$ présentaient au moins une analyse sanguine positive au S. pneumoniae. Par rapport aux 394 patients dont l'analyse sanguine était négative, les patients bactériémiques étaient plus jeunes (55,6 ans par rapport à 63,4 ans; $\mathrm{P}=0,002$ ). À la présentation, les patients bactériémiques affichaient une température orale moyenne plus élevée $\left(38,1 \pm 1,2{ }^{\circ} \mathrm{C}\right.$ par rapport à $37,7 \pm 1,2{ }^{\circ} \mathrm{C}$; $\mathrm{P}=0,026)$, une fréquence plus élevée du pouls $(108,4 \pm 22,1$ battements/min par rapport à $102,1 \pm 20,6$ battements/min; $\mathrm{P}=0,033)$, une tension artérielle diastolique moins élevée $(66,8 \pm 12,7 \mathrm{mmHg}$ par rapport à $73,8 \pm 15,8 \mathrm{mmHg} ; \mathrm{P}=0,001)$ et un plus fort pourcentage de globules blancs à noyau incurvé $(22,1 \%$ par rapport à $14,2 \% ; \mathrm{P}=0,0007)$. Le délai entre l'apparition des symptômes et l'hospitalisation était plus court parmi les patients bactériémiques $(4,6 \pm 3,7$ jours par rapport à $7,0 \pm 13,9$ jours; $\mathrm{P}=0,005)$. Trois types de polysaccharide capsulaire représentaient $53,4 \%$ des isolats : type $14,29,2 \%$; type $4,12,1 \%$; et type $22 \mathrm{~F}, 12,1 \%$. Deux des 44 isolats étaient pénicillinorésistants.

CONCLUSIONS : Bien qu'on remarque certaines différences dans les caractéristiques et la présentation des patients lorsque les patients atteints de pneumonie bactériémique à pneumocoques sont comparés à des patients non bactériémiques atteints de pneumonie acquise dans la collectivité, il existe un chevauchement considérable, et la présentation clinique ne permet pas de distinguer les patients bactériémiques des patients non bactériémiques.
Streptococcus pneumoniae accounts for $60 \%$ of all cases of bacSteremic community-acquired pneumonia (CAP) (1). While bacteremic pneumococcal pneumonia has been described in several studies (2), there has never been a Canada-wide study of the clinical features, processes and outcomes of care of this entity. The present prospective study of CAP at 15 teaching hospitals in eight Canadian provinces gave us the opportunity to accomplish the above goals and, in addition, to compare patients who had bacteremic pneumococcal pneumonia with those who had negative blood cultures

${ }^{1}$ Department of Medicine, University of Alberta, Edmonton, Alberta; ${ }^{2}$ Department of Microbiology, Mount Sinai Hospital, Toronto, Ontario; ${ }^{3}$ Anti-Infectives Group, Pfizer Canada Inc, Kirkland, Quebec

Correspondence and reprints: Dr Thomas J Marrie, 2F1.30 WMC, 8440 - 112 Street, Edmonton, Alberta T6H 0L2. Telephone 780-407-6234, fax780-407-3132,e-mail tom.marrie@ualberta.ca 
for this organism. Further aims of the present study were to determine the serotypes and the antimicrobial susceptibility of the strains of $S$ pneumoniae recovered from these patients.

\section{PATIENTS AND METHODS}

\section{Patient population and study design}

This was a prospective, observational study of CAP requiring initial hospitalization; the study commenced on January 11, 1996, and the last patient was terminated in January 1998. Investigators at 15 teaching hospitals in eight Canadian provinces enrolled patients. Eligible patients were those who were admitted to the hospital with a diagnosis of pneumonia and who met the following criteria:

- 16 years of age or older;

- A new pulmonary infiltrate on chest radiograph not attributable to an alternate cause;

- At least one of:

- symptoms or signs suggestive of pneumonia (chest pain, cough, rales, rhonchi, and/or signs of consolidation); and/or

- oral temperature of $38.5^{\circ} \mathrm{C}$ or higher, or $36.5^{\circ} \mathrm{C}$ or lower.

After informed consent was obtained, a study nurse identified and enrolled patients admitted during day 11 to 30 or 31 (the first 10 days were used for another study that the group was involved in) of each month. The study nurse completed the data collection forms and made daily visits (for a maximum of seven days of follow-up while in hospital) to record progress in terms of the evolution of the pneumonia and any complications that may have occurred during the hospital stay. All data were verified against the original chart by a study monitor during a site visit.

\section{Antibiotic therapy}

Antibiotic therapy was categorized as monotherapy if a single antimicrobial agent was administered and as combination therapy if more than one agent was administered. Combination therapy was further categorized as concurrent if the agents were administered during the same time period for five or more days and as sequential if they overlapped by three days or less.

The first antibiotics that a patient received were termed first-line therapy; a change to an antibiotic of a different class was termed second-line therapy; and so forth for third- and fourth-line therapy.

\section{Diagnostic workup}

Blood cultures were recommended for all patients in the study. The collection of acute and convalescent (four to six weeks after discharge) blood samples was recommended, but the decision was the investigator's. Other aspects of the diagnostic workup were handled by the attending physician.

\section{Microbiology procedures}

Blood and sputum samples were processed for culture at each site's laboratory using standard methods. All serum samples were tested for antibodies to Mycoplasma pneumoniae, influenza viruses $A$ and $B$, parainfluenza viruses 1, 2 and 3 , adenovirus and respiratory syncytial virus (RSV) using a standard complement fixation technique in microtitre plates at the Halifax site. The adenovirus and RSV antigens were purchased from Flow Laboratories (USA); influenza A and B, parainfluenza 1, 2 and 3, and $M$ pneumoniae antigens were purchased from MA Bioproducts (USA).

Patients with bacteremic pneumococcal pneumonia had serum samples tested for immunoglobulin $G$ and immunoglobulin $\mathrm{M}$ antibodies to Chlamydia pneumoniae (AR-39 strain); Chlamydia psittaci (avian strain 6BC, feline pneumonitis strain FP, turkey strain TT3 and pigeon strain CP3); Chlamydia pecorum (ovine polyarthritis strain); and Chlamydia trachomatis (pooled antigens of serovars BED, $\mathrm{CJHI}$ and FGK using the microimmunofluoresence test [tests completed by Dr R Peeling, Laboratory Centre for Disease Control, Winnipeg, Manitoba]) (3). These patients also had serum samples (24 acute and convalescent serum samples, and 22 single serum samples) tested for antibodies to $S$ pneumoniae pneumolysin, pneumolysin immune complexes, C-polysaccharide, surface protein A, Hemophilus influenzae and Branhamella catarrhalis by Dr M Leinonen, National Public Health Institute, Oulu, Finland (4-6).

All serum samples from the patients with bacteremic pneumococcal pneumonia were tested for antibodies to Legionella pneumophila serogroups 1 to 4 by Dr Victor Yu, Pittsburgh, Pennsylvania, using an enzyme-linked immunosorbent assay method (7), and antibodies to Coxiella burnetii phase I and II antigens were determined using a microimmunofluorescence test as previously described (8). All patients had a urine sample collected within $24 \mathrm{~h}$ of admission, which was tested for $L$ pneumophila serogroup 1 antigen (at each study site) using an enzyme-linked immunosorbent assay technique (Binax Inc, USA) (9).

\section{Susceptibility testing of $S$ pneumoniae}

Minimal inhibitory concentrations (MICs), microbroth dilution testing and susceptibility category break points were determined as described by the National Committee on Clinical Laboratory Standards (10). Antibiotics tested included: penicillin, amoxicillin, amoxicillin/clavulanic acid, cefuroxime, ceftriaxone, imipenem, meropenem, trovafloxacin, moxifloxacin, levofloxacin, ciprofloxacin, erythromycin, doxycycline, tetracycline, trimethoprim/sulfamethoxazole, vancomycin and clindamycin. Penicillin resistance was defined to be penicillinnonsusceptible $S$ pneumoniae (MIC $0.1 \mu \mathrm{g} / \mathrm{mL}$ or greater) or penicillin-resistant $S$ pneumoniae (MIC $2 \mu \mathrm{g} / \mathrm{mL}$ or greater).

\section{$S$ pneumoniae capsular polysaccharide typing}

$S$ pneumoniae isolated from the blood of patients with CAP were typed for capsular polysaccharide at the Streptococcal National Reference Centre in Edmonton, Alberta.

\section{Data analysis}

Data was entered into SPSS 8.0 (SPSS Inc, USA). Differences between patient subpopulations were tested using $\chi^{2}$ test or Student's $t$ test for continuous variables. All analysis was conducted using SPSS software. Proportions were compared using the $\chi^{2}$ test or Fisher's exact test, and the difference between means of continuous data was determined using Student's $t$ test (11). 
TABLE 1

Comparison of demographic features of 56 patients having bacteremic Streptococcus pneumoniae pneumonia with 394 patients having blood culture-negative communityacquired pneumonia

\begin{tabular}{|c|c|c|c|}
\hline Demographic feature & $\begin{array}{l}\text { Bacteremic } \\
\text { patients } \\
(n=56)\end{array}$ & $\begin{array}{l}\text { Patients with bloo } \\
\text { cultures negative } \\
\text { ( } n=394)\end{array}$ & $e^{p d}$ \\
\hline Mean ( \pm SD) age (years) & $55.6 \pm 19.1$ & $63.4 \pm 18.1$ & 0.003 \\
\hline Male (n, \%) & $31(55.4)$ & $209(53.0)$ & \\
\hline White (n, \%) & $49(87.5)$ & $368(93.4)$ & \\
\hline \multicolumn{2}{|c|}{$\begin{array}{l}\text { Chronic obstructive pulmonary disease, } 28(50.0) \\
\text { asthma or bronchiectasis }(n, \%)\end{array}$} & $183(46.4)$ & \\
\hline Active cancer $(\mathrm{n}, \%)$ & $4(7.1)$ & $87(22.1)$ & 0.009 \\
\hline Smoked in past year $(\mathrm{n}, \%)$ & $29(51.7)$ & $99(37.9)$ & \\
\hline Influenza vaccine $(n, \%)$ & $22(39.3)$ & $188(47.7)$ & \\
\hline Pneumococcal vaccine $(\mathrm{n}, \%)$ & $3(5.4)$ & $20(5.1)$ & \\
\hline Alcoholism (n, \%) & $9(16.1)$ & $40(10.2)$ & \\
\hline Current smoker (n, \%) & $19(33.9)$ & $112(28.4)$ & \\
\hline
\end{tabular}

TABLE 2

Physical signs in $\mathbf{5 6}$ patients with bacteremic pneumococcal pneumonia compared with 394 patients with blood culture-negative community-acquired pneumonia (CAP)

\begin{tabular}{|c|c|c|c|}
\hline $\begin{array}{r}P d \\
b \\
\text { pn } \\
\text { pneu }\end{array}$ & $\begin{array}{l}\text { Patients with } \\
\text { bacteremic } \\
\text { oneumococcal } \\
\text { leumonia }(n=56)\end{array}$ & $\begin{array}{c}\text { Patients with } \\
\text { blood culture- } \\
\text { negative CAP } \\
(n=394)\end{array}$ & $\mathbf{P}$ \\
\hline Mean $( \pm \mathrm{SD})$ oral temperature $\left({ }^{\circ} \mathrm{C}\right)$ & $38.1 \pm 1.2$ & $37.7 \pm 1.2$ & 0.026 \\
\hline $\begin{array}{l}\text { Mean }( \pm \mathrm{SD}) \text { respiratory rate } \\
\quad \text { (breaths/min) }\end{array}$ & $26.7 \pm 8.3$ & $26.6 \pm 7.5$ & \\
\hline $\begin{array}{l}\text { Mean }( \pm \mathrm{SD}) \text { pulse rate }(\mathrm{SD}) \\
\quad \text { (beats/min) }\end{array}$ & $108.4 \pm 22.1$ & $102.1 \pm 20.6$ & 0.033 \\
\hline $\begin{array}{l}\text { Mean }( \pm \mathrm{SD}) \text { systolic blood } \\
\text { pressure }(\mathrm{mmHg})\end{array}$ & $132.3 \pm 27.9$ & $126.6 \pm 29.0$ & \\
\hline $\begin{array}{l}\text { Mean }( \pm \mathrm{SD}) \text { diastolic blood } \\
\text { pressure }(\mathrm{mmHg})\end{array}$ & $66.8 \pm 12.7$ & $73.8 \pm 5.8$ & 0.001 \\
\hline Crackles (n, \%) & $14(25)$ & $130(33)$ & \\
\hline Wheezes $(n, \%)$ & $13(23.2)$ & $94(23.9)$ & \\
\hline Pleural rub $(n, \%)$ & $2(3.6)$ & $10(2.5)$ & \\
\hline Consolidation (n, \%) & $7(12.5)$ & $42(10.7)$ & \\
\hline
\end{tabular}

\section{RESULTS}

Four hundred fifty of the 850 patients $(52.9 \%)$ enrolled in the study had one or more blood cultures processed, 56 of which $(12.4 \%)$ were positive for $S$ pneumoniae. These 56 patients were compared with 394 patients who had negative blood cultures (Table 1). The bacteremic patients were younger and less likely to have pre-existing cancer than the nonbacteremic patients. There was no difference in the frequency of presenting symptoms when the two groups were compared (data not shown). Table 2 shows that the mean temperature at the time of admission was significantly higher among the bacteremic patients $(\mathrm{P}=0.026)$, as was the mean pulse rate $(\mathrm{P}=0.033)$, while the mean diastolic blood pressure was lower $(\mathrm{P}=0.001)$.

The mean $( \pm \mathrm{SD})$ time from the onset of symptoms until hospitalization was $4.6 \pm 3.7$ days for the bacteremic patients
TABLE 3

Comparison of outcomes and time to presentation for 56 patients with bacteremic pneumococcal pneumonia and 394 patients with blood culture-negative pneumonia

\begin{tabular}{|c|c|c|c|}
\hline Outcome/time & $\begin{array}{l}\text { Patients with } \\
\text { bacteremic } \\
\text { pneumococcal } \\
\text { oneumonia }(n=56)\end{array}$ & $\begin{array}{c}\text { Patients with } \\
\text { blood culture- } \\
\text { negative CAP } \\
(n=394)\end{array}$ & $\mathbf{P}$ \\
\hline Died (n, \%) & $3(5.4)$ & $42(10.7)$ & \\
\hline Admitted to intensive care $(n, \%)$ & $11(19.6)$ & $50(12.7)$ & \\
\hline Mean ( $\pm \mathrm{SD}$ ) length of stay (days) & $8.1(11.3)$ & $7.7(6.5)$ & \\
\hline $\begin{array}{l}\text { Mean }( \pm S D) \text { number of days between } \\
\text { onset of symptoms and presentation }\end{array}$ & $4.6(3.7)$ & $7.0(13.9)$ & 0.005 \\
\hline
\end{tabular}

CAP Community-acquired pneumonia

versus $7.0 \pm 13.9$ days for the nonbacteremic patients $(\mathrm{P}<0.005)$. The mortality rate was lower for the bacteremic group $(5.4 \%)$ than for the nonbacteremic group (10.7\%) $(\mathrm{P}=$ not significant $[\mathrm{NS}])$ (Table 3$)$. The intensive care unit (ICU) admission rate was similar in both groups $-19.6 \%$ for the bacteremic group and $12.7 \%$ for the nonbacteremic group. Seven of the 11 bacteremic patients $(63.6 \%)$ admitted to the ICU required assisted ventilation, compared with 25 of 50 nonbacteremic patients (50\%). The length of hospital stay was similar in both groups. Three of the bacteremic patients (5.4\%) died, while 42 of the nonbacteremic patients $(10.7 \%)$ died $(\mathrm{P}=\mathrm{NS})$.

The mean white blood cell count of the bacteremic patients was $17.4 \times 10^{9} / \mathrm{L}$, compared with $14.2 \times 10^{9} / \mathrm{L}$ for the nonbacteremic patients $(\mathrm{P}=\mathrm{NS})$. The percentage of white cells that were band forms was higher among the bacteremic patients than among the nonbacteremic patients $(22.1 \% \pm 18.5 \%$ versus $14.2 \% \pm 14.2 \%)(\mathrm{P}=0.0007)$. There was a tendency toward multilobar pneumonia among the bacteremic patients (16 of $56,28.5 \%$ ) versus the nonbacteremic patients (72 of 394 , $18.2 \%)(\mathrm{P}=\mathrm{NS})$.

Forty-four per cent of the bacteremic patients waited $4 \mathrm{~h}$ or more from presentation to the emergency room until receipt of antibiotics, compared with $58.3 \%$ of the nonbacteremic patients $(\mathrm{P}=0.055)$. The bacteremic patients received intravenous antibiotics for $8.4 \pm 6.4$ days, while the nonbacteremic patients received antibiotics for $6.7 \pm 6.0$ days $(\mathrm{P}=0.04)$.

Twenty-one patients $(37.5 \%)$ with bacteremic pneumococcal pneumonia received treatment with a single antibiotic, compared with $39.8 \%$ of the nonbacteremic group. A secondgeneration cephalosporin was used as the single agent for 14 of 21 bacteremic patients $(66.7 \%)$; two $(9.5 \%)$ received a macrolide and four (19\%) received other antibiotics. Thirtyfive bacteremic patients $(62.5 \%)$ received combination therapy, compared with 219 nonbacteremic patients (55.5\%) $(\mathrm{P}=0.029)$. A second-generation cephalosporin and a macrolide were used to treat 29 of 35 bacteremic patients $(82.8 \%)$ who received combination therapy. Fifty-three bacteremic patients $(94.6 \%)$ received second-line antibiotic therapy, compared with 349 nonbacteremic patients $(88.5 \%)$ $(\mathrm{P}=\mathrm{NS})$. However, more bacteremic patients received a thirdline antibiotic than nonbacteremic patients (Table 4). Eventually, 34 of the bacteremic patients $(60.7 \%)$ received penicillin $(n=27)$ or amoxicillin $(n=7)$. 
TABLE 4

Number (\%) of 56 bacteremic pneumococcal pneumonia patients and 394 nonbacteremic patients with communityacquired pneumonia (CAP) who received second-, thirdand fourth-line antibiotic therapy

\begin{tabular}{lccc}
\hline Antibiotic therapy & $\begin{array}{c}\text { Patients with } \\
\text { bacteremic } \\
\text { pneumococcal } \\
\text { pneumonia (n=56) }\end{array}$ & $\begin{array}{c}\text { Patients with } \\
\text { blood culture- } \\
\text { negative CAP } \\
\text { (n=394) }\end{array}$ & P \\
\hline Second-line & $53(94.6)$ & $350(88.8)$ & NS \\
Third-line & $25(44.6)$ & $112(28.4)$ & 0.014 \\
Fourth-line & $5(8.9)$ & $18(4.6)$ & NS \\
\hline
\end{tabular}

The capsular polysaccharide types for 41 of the isolates are shown in Table 5 . Three serotypes accounted for $53.4 \%$ of the isolates - type $14,29.2 \%$; type 4, 12.1\%; type $22 \mathrm{~F}, 12.1 \%$.

Forty-four isolates were tested for susceptibility to 24 different antibiotics (Table 6). Only two of the isolates were resistant to penicillin, one of which was also resistant to cefotaxime, ceftriaxone and cefuroxime. Both of these isolates were from Ontario sites. There was no erythromycin resistance observed. One of the patients with penicillin-resistant S pneumoniae was a 73-year-old woman with chronic obstructive pulmonary disease and a one hundred pack-year history of tobacco smoking. She was treated with erythromycin and ciprofloxacin, and was discharged after a 15-day hospital stay. The second patient was a 50-year-old man with a history of alcoholism who was treated with ceftriaxone and discharged after a four-day hospital stay.

Table 7 shows the results of the serodiagnosis of pneumococcal pneumonia among 46 of the bacteremic patients who had serum specimens available for testing. Eighty-three per cent of those with acute and convalescent samples had a positive test, while $31.8 \%$ of those with an acute phase sample only had a positive test. Overall, $58.7 \%$ of the patients tested had a positive serological test indicating infection with $S$ pneumoniae. Seven patients $(15.2 \%)$ had evidence of infection with another pathogen. These pathogens included respiratory syncytial virus (RSV) and influenza A in one patient, RSV and C pneumoniae in another patient, and one of influenza $\mathrm{A}$, influenza $\mathrm{B}$, Coxiella burnetii, $\mathrm{C}$ pneumoniae and parainfluenza virus 3 in five patients. Fifty-one nonbacteremic patients $(22.8 \%)$ had two or more pathogens identified as the etiology of the pneumonia.

\section{DISCUSSION}

Fifty-six of the 450 patients (12.4\%) who had blood cultures performed had bacteremic $S$ pneumoniae pneumonia. This is higher than the $4.2 \%$ rate (47 of 1118 patients) reported in a study carried out at a single hospital in Halifax from November 1981 to May 1990 (1). In another North American study carried out in Boston, Massachusetts; Pittsburgh, Pennsylvania; and Halifax from October 1991 to March 1994, 63 of 1343 patients (4.6\%) requiring hospitalization for CAP had S pneumoniae isolated from the blood (12). Marston et al (13) found that $5.5 \%$ of 2776 patients with CAP hospitalized in two counties in Ohio had S pneumoniae bacteremia. Mundy et al (14) noted that 31 of 385 patients $(8 \%)$ with CAP requiring admission to the Johns Hopkins Hospital, 180 of whom had human immunodeficiency virus infection, had pneumococcal bacteremia.
TABLE 5

Capsular polysaccharide types for $\mathbf{4 1}$ isolates from patients with bacteremic pneumococcal pneumonia

\begin{tabular}{lrr}
\hline Type & $\mathbf{n}$ & $\%$ \\
\hline 3 & 1 & 2.4 \\
4 & 5 & 12.1 \\
$6 \mathrm{~A}$ & 1 & 2.4 \\
8 & 3 & 7.3 \\
$9 \mathrm{~N}$ & 1 & 2.4 \\
$9 \mathrm{~V}$ & 3 & 7.3 \\
$10 \mathrm{~A}$ & 2 & 4.8 \\
$12 \mathrm{~F}$ & 1 & 2.4 \\
14 & 12 & 29.2 \\
$16 \mathrm{~F}$ & 1 & 2.4 \\
$18 \mathrm{C}$ & 2 & 4.8 \\
$19 \mathrm{~F}$ & 1 & 2.4 \\
20 & 2 & 4.8 \\
$22 \mathrm{~F}$ & 5 & 12.1 \\
$33 \mathrm{~F}$ & 1 & 2.4 \\
\hline
\end{tabular}

Risk factors for pneumococcal pneumonia that have been mentioned in other studies are dementia, seizure disorders, current cigarette smoking, congestive heart failure, cerebrovascular disease, institutionalization, chronic obstructive pulmonary disease, lung cancer, corticosteroid use and alcoholism (15). Musher et al (2) found that $58 \%$ of 52 patients with bacteremic pneumococcal pneumonia had a history of alcohol abuse, compared with $35 \%$ of 48 patients with nonbacteremic pneumococcal pneumonia $(\mathrm{P}=0.03)$. Most of the patients $(98 \%)$ in Musher's study were male and all were hospitalized at a Veterans Affairs Medical Center, both of which may be confounding factors. We did not find these factors to be significant in our study.

The mortality rate of $5.3 \%$ among our patients with bacteremic pneumococcal pneumonia is low and may be due in part to enrolment bias. Since providing informed consent was necessary for all patients to participate, very ill patients were often not enrolled in the study. Another possible explanation for the low mortality rate is the shorter time between onset of symptoms and presentation for the bacteremic patients - 4.6 days versus 7.0 days for the nonbacteremic patients. In a previous study of all patients with bacteremic pneumococcal pneumonia, we found that the mortality rate was 19\% (1). Kalin et al (16) studied 460 patients with bacteremic pneumococcal pneumonia from September 1, 1993 to August 31, 1995 at five centres in Halifax; Huntington, West Virginia; Barcelona, Spain; Manchester, United Kingdom; and Stockholm, Sweden. The overall mortality rate was $12 \%$, ranging from $6 \%$ in Halifax to $20 \%$ in Barcelona and Huntington. Musher et al (2), in their study of 52 bacteremic pneumococcal pneumonia patients at a Veterans Affairs Medical Center in Houston, Texas from September 1996 through 1999, found that the seven-day mortality rate was $19 \%$, while the 30 -day and 90 -day mortality rates were $21 \%$ and $27 \%$, respectively (2). In a study carried out during the preantibiotic era from 1929 to 1935, Tilghman and Finland (17) found that $77.5 \%$ of 582 bacteremic patients died. 
TABLE 6

Minimal inhibitory concentrations of various antibiotics required to inhibit $50 \%\left(\mathrm{MIC}_{50}\right)$ and $90 \%\left(\mathrm{MIC}_{90}\right)$ of 44 isolates of Streptococcus pneumoniae from patients with bacteremic pneumococcal pneumonia

\begin{tabular}{|c|c|c|c|c|}
\hline Antibiotic (cut-point for resistance) & $\mathrm{MIC}_{50}(\mu \mathrm{g} / \mathrm{mL})$ & $\mathrm{MIC}_{90}(\mu \mathrm{g} / \mathrm{mL})$ & Range $(\mu \mathrm{g} / \mathrm{mL})$ & Resistance (\%) \\
\hline $\begin{array}{l}\text { Penicillin ( } 0.12 \text { to } 1 \text { - nonsusceptible; } \\
2 \text { or greater - resistant) }\end{array}$ & 0.03 & 0.03 & 0.03 to 0.12 & $4.5 \%$ \\
\hline Amoxicillin (1) & 0.03 & 0.06 & 0.03 to 0.12 & 0 \\
\hline Amoxicillin/clavulanic acid (1/0.5) & 0.06 & 0.06 & 0.03 to 0.12 & 0 \\
\hline Cefuroxime (1) & 0.25 & 0.25 & 0.25 to 2 & 2.2 \\
\hline Ceftriaxone & 0.03 & 0.06 & 0.03 to 1.0 & 2.2 \\
\hline Cefotaxime & 0.03 & 0.03 & 0.03 to 1.0 & 2.2 \\
\hline Imipenem & 0.03 & 0.06 & 0.03 to 0.06 & 0 \\
\hline Meropenem & 0.03 & 0.03 & 0.03 to 0.06 & 0 \\
\hline Trovafloxacin & 0.12 & 0.25 & 0.06 to 0.25 & 0 \\
\hline Gatifloxacin & 0.12 & 0.12 & 0.06 to 0.25 & \\
\hline Grepafloxacin & 0.25 & 0.25 & 0.12 to 0.25 & 0 \\
\hline Moxifloxacin & 0.25 & 0.25 & 0.12 to 0.25 & \\
\hline Levofloxacin & 1 & 1 & 0.5 to 1.0 & 0 \\
\hline Ofloxacin & 2 & 2 & 1.0 to 2.0 & 0 \\
\hline Ciprofloxacin & 1 & 1 & 0.5 to 2.0 & \\
\hline Erythromycin (0.5) & $\leq 0.12$ & 0.12 & 0.12 & 0 \\
\hline Doxycycline & $\leq 1$ & 1 & 1 & \\
\hline Tetracycline (4) & $\leq 1$ & 1 & 1 & 0 \\
\hline Trimethoprim & 2 & 4 & 0.25 to 32 & \\
\hline Trimethoprim/sulfamethoxazole & 0.25 & 0.50 & 0.25 to 4 & 16 \\
\hline Vancomycin & $\leq 0.50$ & 0.50 & 0.5 & \\
\hline Chloramphenicol (8) & 2 & 4 & 2 to 4 & 0 \\
\hline Clindamycin $(0.25)$ & $\leq 0.25$ & 0.25 & 0.25 & 0 \\
\hline Dalfopristin/quinapristin & 0.50 & 0.50 & 0.25 to 0.5 & \\
\hline
\end{tabular}

TABLE 7

Results of testing for antibodies to pneumolysin,

C-polysaccharide, pneumococcal surface protein and

pneumolysin immune complexes in 46 patients with bacteremic pneumococcal pneumonia

\begin{tabular}{lcc}
\hline Phase & n & $\begin{array}{c}\text { Number of positive } \\
\text { results (\%) }\end{array}$ \\
\hline Acute and convalescent serum samples & 24 & $20(83.3)$ \\
Acute phase only & 22 & $7(31.8)$ \\
Total & 46 & $27(58.7)$ \\
\hline
\end{tabular}

Austrian and Gold (18), in a study carried out just after penicillin had been introduced as a therapy for pneumococcal pneumonia, noted that $24.7 \%$ of patients with pneumococcal bacteremia died and that $60 \%$ of all deaths among patients treated with penicillin occurred during the first five days, suggesting that antimicrobial therapy has little or no effect on the outcome of infection among those destined to die within five days. Hook et al (19) noted that there was a $30.5 \%$ overall mortality rate from pneumococcal bacteremia and a 76\% mortality rate among those admitted to ICUs. Some of these findings remain to be explained but likely reflect both host and micro-organism factors.

There were no statistically significant differences in symptoms when patients with pneumococcal bacteremia were compared with those with pneumonia and negative blood cultures

for $S$ pneumoniae. Twenty-five per cent of the bacteremic patients had diarrhea. Severe diarrhea can occur in pneumococcal pneumonia $(20,21)$ and was termed 'croupous colitis' by Osler (20). It has been suggested that this diarrhea is due to invasion of the intestinal wall and the mesenteric lymph nodes by $S$ pneumoniae (22).

Pleuritic chest pain was slightly more frequent among those with bacteremia $-46.4 \%$ versus $38.9 \%$ for the nonbacteremic patients. This is lower than the findings in our previous study, in which $62 \%$ of the bacteremic patients complained about pleuritic chest pain (1). In a study of 1343 patients requiring hospitalization for the treatment of CAP, Fine et al (23) found that $39.4 \%$ patients had pleuritic chest pain. It seems likely that pleuritic chest pain does occur in a greater proportion of patients with bacteremic pneumococcal pneumonia than other patients with CAP.

There were, however, differences in physical findings - the bacteremic patients had a higher temperature and pulse rate, and a lower diastolic blood pressure than the nonbacteremic patients.

There are now 90 serotypes of S pneumoniae recognized (24), and the lower numbered serotypes are more pathogenic for man (17). Indeed, in the 1930s, serotypes 1, 2, 3 accounted for $75 \%$ of bacteremias (17). In a study of 7000 episodes of invasive pneumococcal disease from Europe, South America and North America, 12 serotypes (or groups) accounted for $80.9 \%$ of all isolates (25). Types 14, 22F, 6, 19 and 3 were the most common and 
accounted for nearly $40 \%$; types $23,1,9$ and 4 for about $25 \%$; and types $8,18,7$ and 5 for approximately $15 \%$ of all isolates.

This study also demonstrated important geographic and agerelated variations in the distribution of serotypes. Even though the number of isolates that we serotyped was small, the distribution generally confirms what is stated above. Type 14 was the most common serotype, accounting for $29.2 \%$ of the isolates; indeed, types 14, 6, 19 and 3 collectively accounted for $36.4 \%$ of our isolates. Types 9 and 4 accounted for $21.8 \%$, and types 8,18 and 7 accounted for $12.1 \%$ of the isolates. We also noted geographic variation; six of the 12 type 14 isolates were from patients at the Winnipeg site, and three of the five $22 \mathrm{~F}$ isolates were from patients at the Halifax site. Thirteen isolates were typed from the Winnipeg site and 10 from the Halifax site. In a previous study at the Winnipeg site, Mirzanejad et al (26) found that, over an eight-year period, type 14 was the most common cause of pneumococcal bacteremia, accounting for 32 of 217 isolates (14.7\%).

Henriques et al (27) serotyped 354 isolates from the patients with bacteremic pneumococcal pneumonia studied by Kalin et al (16). They noted that serotype 14 was most common, accounting for $14 \%$ of the isolates, followed by type $9 \mathrm{~V}$ at $11 \%$, type 3 at $9 \%$, type $23 \mathrm{~F}$ at $9 \%$ and $7 \mathrm{~F}$ at $8 \%$. They also noted a marked difference in the serotype distribution according to country of origin of the patient, with serotype 3 dominating in Spain and the United States, and type 14 dominating in Sweden and Canada.

During 1997 and 1998, Zhanel et al (28) tested 1180 $S$ pneumoniae isolates collected across Canada for susceptibility to a variety of antibiotics. They found that $251(21.2 \%)$ were penicillin nonsusceptible (intermediate susceptibility plus resistance). Davidson et al (29) examined 1320 isolates of S pneumoniae collected from sites across Canada in 1994/1995, as well as 1044 isolates in 1996. They found that the percentage of penicillin-nonsusceptible isolates increased from 8.5\% in $1994 / 1995$ to $13.3 \%$ in 1996 . How do we reconcile these observations with our data, in which only two of 44 bacteremic isolates (4.5\%) collected during 1996/1997 were penicillinnonsusceptible? There are several possible explanations; for instance, we examined isolates only from adults with bacteremic pneumococcal pneumonia. Age younger than four years is one of the factors associated with penicillin-resistant $S$ pneumoniae $(30,31)$.

In the studies cited above $(28,29)$, the $S$ pneumoniae isolates were from a variety of respiratory tract sites and included all ages. It is also possible that the penicillin-nonsusceptible isolates are less virulent and hence would be under-represented in any study that examined only blood isolates. Against this argument is the observation by Plouffe et al (32) that the incidence of drug-resistant, bacteremic $S$ pneumoniae isolates increased to $14 \%$ during their study of 590 patients at 10 adult care hospitals in Franklin County, Ohio from January 1991 to April 1994. The most recent and comprehensive data comes from a 1995 to 1998 study of 4013 cases of invasive S pneumoniae in the United States (33). In 1998, 24\% of the isolates were resistant to penicillin, and over the period of the study, the proportion of the isolates that were resistant to three or more classes of drugs increased from $9 \%$ to $14 \%$ (33).

A method of diagnosing pneumococcal pneumonia that does not depend on sputum culture is desirable. In most studies of CAP, at least $30 \%$ of the cases are of unknown etiology despite an intensive diagnostic workup $(14,34)$. The pneumococcal serological studies used in this and other studies (35-38) are of great interest, because they offer the possibility of making an etiological diagnosis of pneumococcal pneumonia in the absence of sputum specimens and in those with negative blood cultures. However, these studies need validation against a gold standard. Bacteremic pneumococcal pneumonia is one such standard.

It is noteworthy that three studies $(36-38)$ that used serological methods in addition to blood and sputum cultures in the diagnosis of pneumococcal pneumonia had the highest rates of infection due to this micro-organism. In these studies, $42.8 \%$ (36), 32\% (37) and 55\% (38) of the cases of pneumonia were due to $S$ pneumoniae, compared with $15.3 \%$ and $17.9 \%$ for studies that did not use this methodology $(34,14)$. We found that $83.3 \%$ of the bacteremic patients who had acute and convalescent serum samples tested met the criteria for the serological diagnosis of $S$ pneumoniae infection. This is almost identical to the $88 \%$ sensitivity found by Porath et al (35) in a study of 22 bacteremic pneumococcal pneumonia patients. If an acute phase sample only was available, the sensitivity in our patients was only $31.8 \%$. We conclude that, at present, serological testing is not useful as a method of diagnosing pneumococcal pneumonia.

We found that $15 \%$ of the 46 patients with serum available for serological testing had evidence of infection with another pathogen. Marston et al (13) found that 14 of 154 patients (9\%) with bacteremic pneumococcal pneumonia had evidence of infection with another pathogen. They noted that one patient had group A streptococcus bacteremia, one had Staphylococcus aureus bacteremia, two had four-fold rises in antibody titre to Legionella species, five had M pneumoniae, three had C pneumoniae, one had influenza A and one had RSV.

In the current study, in addition to $S$ pneumoniae, RSV and influenza A were found in one patient; RSV and C pneumoniae were found in one patient, and influenza $\mathrm{A}$, influenza B, $\mathrm{C}$ burnetii, $\mathrm{C}$ pneumoniae and parainfluenza virus 3 were each found alone in five patients. In a previous study, eight of 47 patients $(17 \%)$ had a potential pathogen in addition to $S$ pneumoniae isolated from the sputum, and eight of 32 patients (25\%) had serological evidence of infection with another pathogen: parainfluenza 3, three patients; influenza $\mathrm{A}$, one patient; influenza $\mathrm{B}$, one patient; RSV, one patient; cytomegalovirus, one patient; and C burnetii, one patient (1). Collectively, these observations indicate that a proportion of patients with bacteremic pneumococcal pneumonia are infected with a second, and occasionally even a third, pathogen.

\section{CONCLUSIONS}

While the clinical picture of bacteremic $S$ pneumoniae pneumonia is very similar to that of CAP with blood cultures negative for $S$ pneumoniae, a number of significant differences were noted in the present study in terms of age, underlying disease, vital signs and time from onset of symptoms until presentation. Although outcomes between bacteremic $S$ pneumoniae pneumonia and nonbacteremic pneumonia were similar, there was a tendency toward better outcomes for the bacteremic S pneumoniae patients. A possible explanation is that the nonbacteremic patients presented seven days after the onset of symptoms, while bacteremic $S$ pneumoniae pneumonia patients presented 4.6 days after the onset of symptoms. 
ACKNOWLEDGEMENTS: Members of the Canadian Community-Acquired Pneumonia Study Group: Dr R Duperval, University of Sherbrooke, Sherbrooke, Quebec; Dr S Field and Dr T Louie, University of Calgary, Calgary, Alberta; Dr S Houston, University of Alberta, Edmonton, Alberta; Dr M Gribble, University of British Columbia, Vancouver, British Columbia; Dr K Williams, University of Saskatchewan, Saskatoon, Saskatchewan; Dr L Nicolle, University of Manitoba, Winnipeg, Manitoba; Drs R Grossman and I Salit, University of Toronto, Toronto, Ontario; Dr R Saginur, University of Ottawa, Ottawa, Ontario; Dr D Gregson, University of Western Ontario, London, Ontario; Dr M Laverdière, Universite de Montreal, Montreal, Quebec; Dr M Rouleau, Universite Laval, Quebec City, Quebec; and Dr J Hutchinson, Memorial University of Newfoundland, St John's, Newfoundland. We express our thanks to the following study coordinators: M Dumbreville RN, H Salts RN, J Clark-DiPrata RN, B Peters RN, K Heney RN, J Graham RN, F Brisebois RN, H Patil RN, G Patrick RN, T Muir RN, F Hebel RN, E Condon RN, S Roberts RN, A Lindemulder RN, D PagetDellio RN, M Jones RN and C Hammerberg RN, as well as to J Inverso PhD, S Ioannou MSc and N Moghaddam BSc. Funding support was provided by Pfizer Canada Inc.

\section{REFERENCES}

1. Marrie TJ. Bacteremic pneumococcal pneumonia: A continuously evolving disease. J Infect 1992;24:247-55.

2. Musher DM, Alexandraki I, Graviss EA, et al. Bacteremic and non-bacteremic pneumococcal pneumonia. A prospective study. Medicine 2000;79:210-21

3. Wang S-P, Kuo C-C, Grayston JT. Formalized Chlamydia trachomatis organisms as antigens in the microimmunofluorescence test. J Clin Microbiol 1979;10:259-61.

4. Jalonen E, Taira S, Paton JC, et al. Pneumolysin produced in Bacillus subtilis as antigen for measurement of pneumococcal antibodies by enzyme immunoassay. Serodiagn Immunother Infect Dis 1990;4:451-8

5. Jalonen E, Paton JC, Koskela M, et al. Measurement of antibody responses to pneumolysin - A promising method for the presumptive etiological diagnosis of pneumococcal pneumonia. J Infect 1989;19:127-34

6. Leinonen M, Syrjala H, Jalonen E, et al. Demonstration of pneumolysin antibodies in dissociated immune complexes A new method for etiological diagnosis of pneumococcal pneumonia. Serodiagn Immunother Infect Dis 1990;4:459-68.

7. Elder EM, Brown A, Remington JS, et al. Microenzyme-linked immunoabsorbent assay for detection of immunoglobulin $\mathrm{G}$ and immunoglobulin $\mathrm{M}$ antibodies to Legionella pneumophila. J Clin Microbiol 1983;17:112-21.

8. Marrie TJ, Van Buren J, Faulkner RS, et al. Seroepidemiology of Q fever in Nova Scotia and Prince Edward Island. Can J Microbiol 1984;30:129-34.

9. Berdal BP, Farshy CE, Feeley JC. Detection of Legionella pneumophila antigen in urine by enzyme-linked immunospecific assay. J Clin Microbiol 1979;9:575-8.

10. Chen DK, McGeer A, De Azavedo JC, et al for the Canadian Bacterial Surveillance Network. Decreased susceptibility of Streptococcus pneumoniae to fluoroquinolones in Canada. N Engl J Med 1999;341:233-9.

11. Norusis MJ. SPSS 8.0 Guide to Data Analysis. Upper Saddle River: Prentice Hall, 1998.

12. Brandenburg JA, Marrie TJ, Coley CM, et al. Clinical presentation, processes and outcomes of care for patients with pneumococcal pneumonia. J Gen Intern Med 2000;15:638-46.

13. Marston BJ, Plouffe JF, File TM Jr, et al. Incidence of communityacquired pneumonia requiring hospitalization. Results of a population-based active surveillance study in Ohio. Arch Intern Med 1997;157:1709-18.
14. Mundy LM, Auwaerter PG, Oldach D, et al. Community-acquired pneumonia: Impact of immune status. Am J Respir Crit Care Med 1995;152:1309-15

15. Lipsky BA, Boyko EJ, Innui TS, et al. Risk factors for acquiring pneumococcal infections. Arch Intern Med 1986;146:2179-85.

16. Kalin M, Ortqvist A, Almela M, et al. Prospective study of prognostic factors in community-acquired bacteremic pneumococcal disease in 5 countries. J Infect Dis 2000;182:840-7.

17. Tilghman RC, Finland M. Clinical significance of bacteremia in pneumococcal pneumonia. Arch Intern Med 1937;59:602-19.

18. Austrian R, Gold J. Pneumococcal bacteremia with especial reference to bacteremic pneumococcal pneumonia. Ann Intern Med 1964;60:759-76

19. Hook EW 3rd, Horton CA, Schaberg DR. Failure of intensive care unit support to influence mortality from pneumococcal bacteremia. JAMA 1983;249:1055-7.

20. del Rio C, McGowan JE. Severe diarrhea in pneumococcal bacteremia: Croupous colitis. JAMA 1987;257:189. (Lett)

21. Guerin JM, Meyer, Habib Y. Severe diarrhea in pneumococcal bacteremia.. JAMA 1987;257:1897-8.

22. Fernandez-Guerrero ML, Renedo G, Jimenez-Diaz F. Severe diarrhea in pneumococcal bacteremia. JAMA 1987;257:1898. (Lett)

23. Fine MJ, Stone RA, Singer DE, et al. Processes and outcomes of care for patients with community-acquired pneumonia. Results from the Pneumonia Patient Outcomes Research Team (PORT) cohort study. Arch Intern Med 1999;159:970-80.

24. Henrichsen J. Six newly recognized types of Streptococcus pneumoniae. J Clin Microbiol 1995;33:2759-62.

25. Scott JA, Hall AJ, Dagan R, et al. Serogroup-specific epidemiology of Streptococcus pneumoniae: associations with age, sex, and geography in 7,000 episodes of invasive disease. Clin Infect Dis 1996;22:973-81.

26. Mirzanejad Y, Roman S, Talbot J, et al, and the Pneumococcal Bacteremia Study Group. Pneumococcal bacteremia in two tertiary care hospitals in Winnipeg, Canada. Chest 1996;109:173-8.

27. Henriques B, Kalin M, Ortqvist A, et al. Molecular epidemiology of Streptococcus pneumoniae causing invasive disease in 5 countries. J Infect Dis 2000;182:833-9.

28. Zhanel GG, Karlowsky JA, Palatnick L, et al. Prevalence of antimicrobial resistance in respiratory tract isolates of Streptococcus pneumoniae: Results of a Canadian National Surveillance Study. Antimicrob Agents Chemother 1999;43:2504-9.

29. Davidson R, Canadian Bacterial Surveillance Network, Low DE. A cross Canada surveillance of antimicrobial resistance in respiratory tract pathogens. Can J Infect Dis 1999;10:128-33.

30. Nava JM, Bella F, Garau J, et al. Predictive factors for invasive disease due to penicillin-resistant Streptococcus pneumoniae: A population based study. Clin Infect Dis 1994;19:884-90.

31. Zangwill KM, Vadheim CM, Vannier AM, et al. Epidemiology of invasive pneumococcal disease in southern California: Implications for the design and conduct of a pneumococcal conjugate vaccine efficacy trial. J Infect Dis 1996;174:752-9.

32. Plouffe JF, Breiman RF, Facklam RR, et al. Bacteremia with Streptococcus pneumoniae. Implications for therapy and prevention. JAMA 1996;275:194-8.

33. Whitney CG, Farley MM, Hadler J, et al. Increasing prevalence of multidrug-resistant Streptococcus pneumoniae in the United States. N Engl J Med 2000;343:1917-24.

34. Fang G-D, Fine M, Orloff J, et al. New and emerging etiologies for community-acquired pneumonia with implications for therapy. A prospective multicenter study of 359 cases. Medicine 1990;69:307-16.

35. Porath A, Schlaeffer F, Pick N, et al. Pneumococcal communityacquired pneumonia in 148 hospitalized adult patients. Eur J Clin Microbiol Infect Dis 1997;16:863-70.

36. Kauppinen M T, Herva E, Kujala P, et al. The etiology of communityacquired pneumonia among hospitalized patients during a Chlamydia pneumoniae epidemic in Finland. J Infect Dis 1995;172:1330-5.

37. Burman LA, Trollfors B, Andersson B, et al. Diagnosis of pneumonia by cultures, bacterial and viral antigen detection tests, and serology with special reference to antibodies against pneumococcal antigens. J Infect Dis 1993;163:1087-93.

38. Porath A, Schlaeffer F, Lieberman D. The epidemiology of community-acquired pneumonia among hospitalized adults. J Infect Dis 1997;34:41-8. 


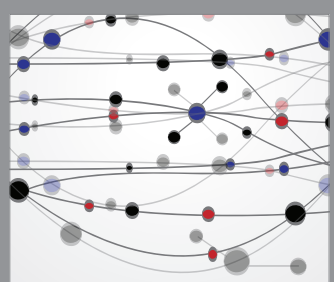

The Scientific World Journal
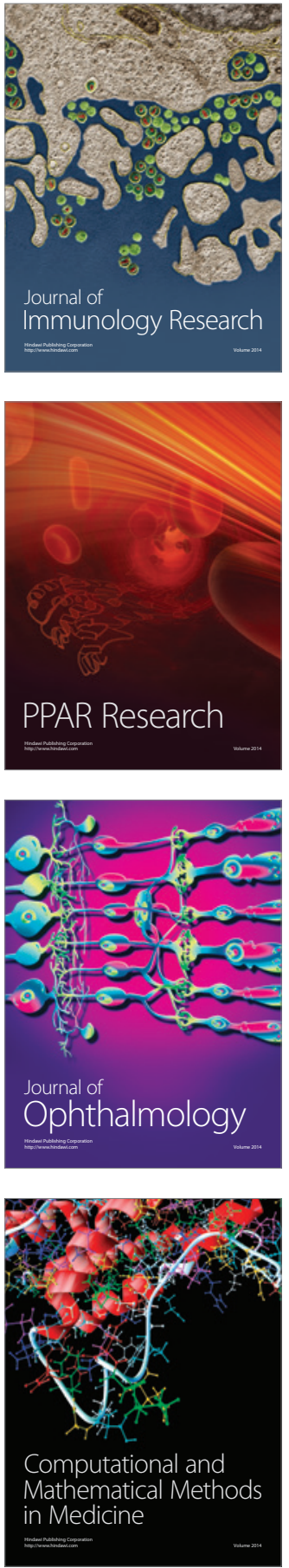

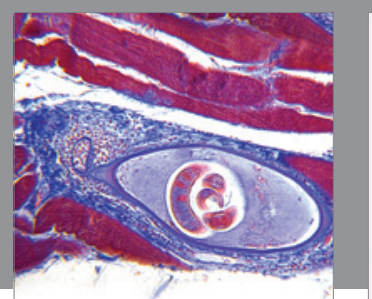

Gastroenterology Research and Practice

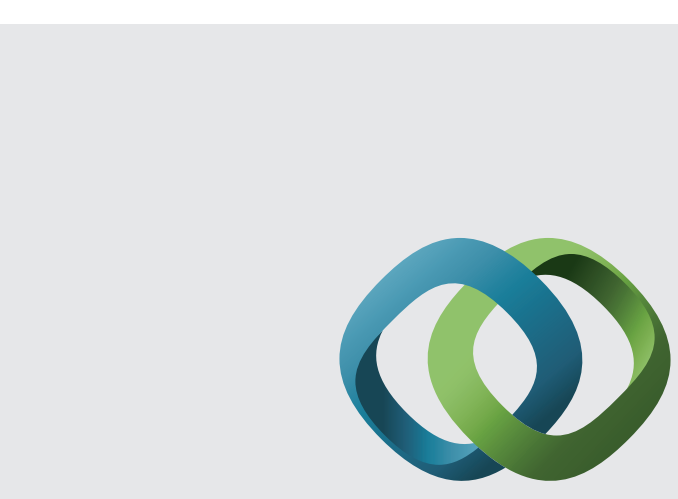

\section{Hindawi}

Submit your manuscripts at

http://www.hindawi.com
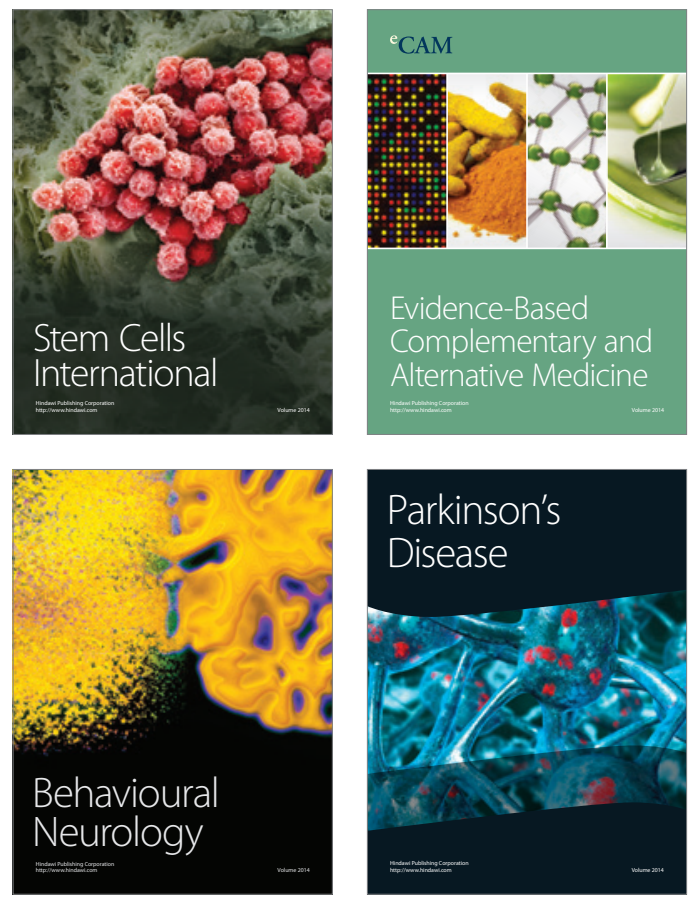
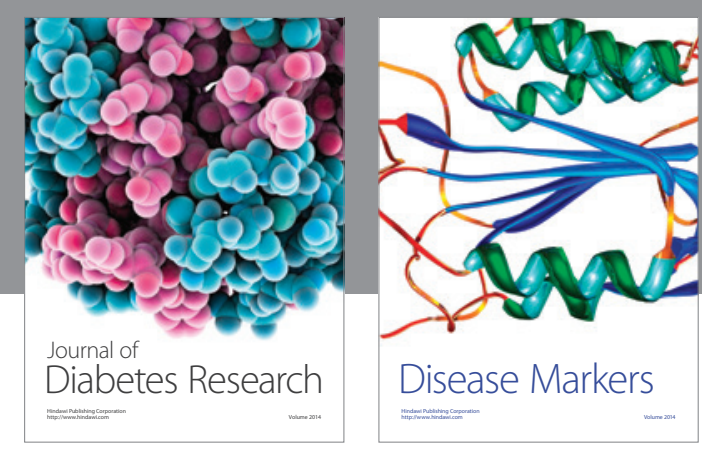

Disease Markers
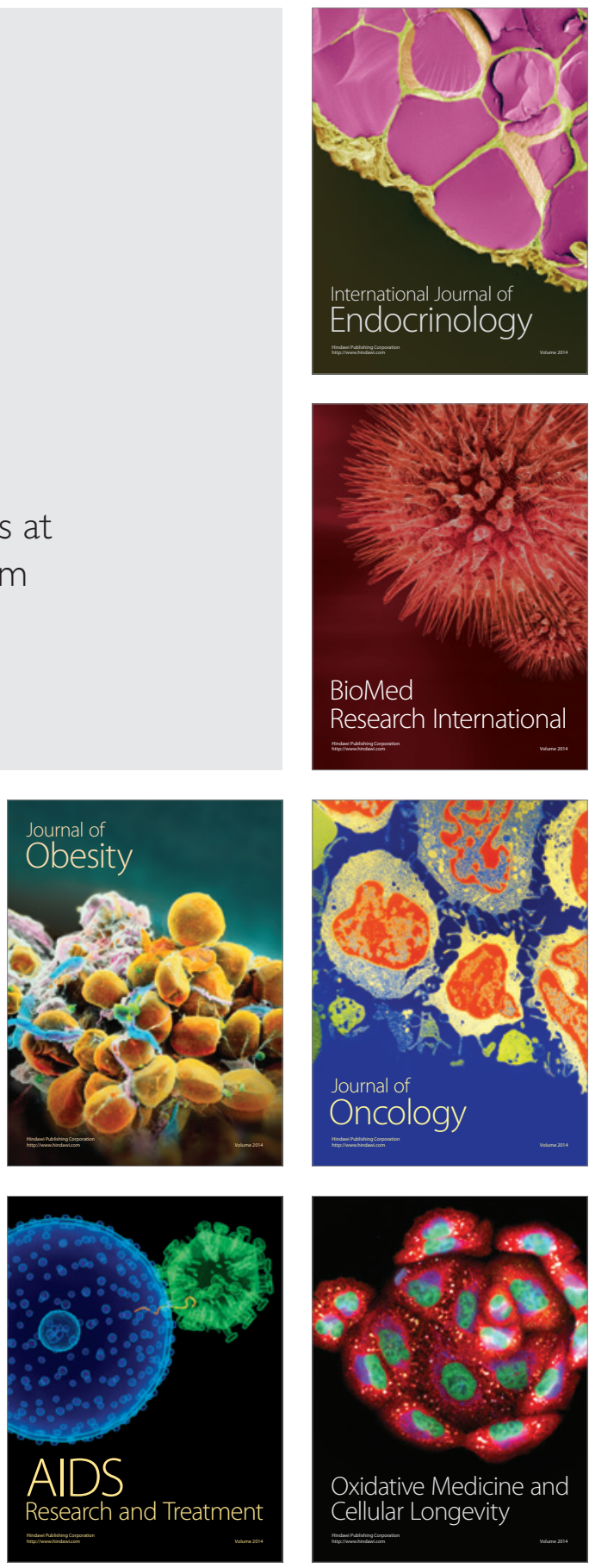